كميتـهُ مستقل مشترك نظارت و ارزيابى مبـارزه عليه فسـاد ادارى

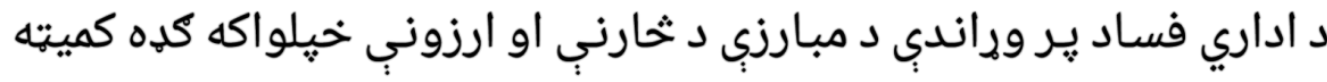

Independent Joint Anti-corruption Monitoring and Evaluation Committee

\title{
Monitoring and Evaluation Committee (MEC) Rejects Pajhwok Report on MEC's Findings about the Ministry of Foreign Affairs
}

Kabul - October 8, 2018

In September 2017, MEC started working on an Inquiry on vulnerability to corruption on the recruitment and deployment processes within the Ministry of Foreign Affairs (MoFA). While this report is still in initial draft form and several steps away from being finalized, Pajhwok News Agency accessed some of the raw material from the draft report and published a news report in the name of MEC. MEC firmly states that Pajhwok's news report is incomplete, unprofessional and irresponsible and rejects it.

MEC has a specific process it works through before commencing, finalizing, and releasing one of its reports to the public. First, it seeks the agreement of a relevant entity or ministry they've chosen to assess for corruption, then assigns a technical team to collect data on vulnerabilities to corruption in the said institution and compile the findings in the form of a first draft report. Next, they shares the first draft report with the relevant entity, donors and other stakeholders and develops a second draft of the report based on comments and critiques on the first draft. The Committee presents the second draft to the High Council for Rule of Law and Anti-Corruption, in the presence of the President. Lastly, after input from the Council, MEC finalizes the report and officially releases in a press conference in three languages. Throughout all the above steps, the report might change to an extent that will alter its complete essence and content.

Since the draft report of the MoFA Inquiry has not yet gone through any of the aforementioned steps for review and comments, the MEC considers the publishing of the Pajhwok report (October $4^{\text {th }}, 2018$ ) to be based on only parts of the initial draft copy, an unprofessional and irresponsible act that can harm the credibility of their news agency and affect MEC's work.

Pajhwok stated in the news report that they sought MEC Chairman Mr. Barry Salaam's view on the issue. Although Pajhwok News Agency contacted Mr. Salaam and other officials at MEC inquiring about the overall work of the MEC, and were granted a date to meet at MEC, they made no mention of the Ministry of Foreign Affairs Inquiry, nor did they meet with anyone at MEC on the matter on which they reported.

We ask the Pajhwok News Agency, as a reputed news organization and our media partner, to recant their published story on our MoFA Inquiry as incomplete and lacking credible sources.

The MEC is planning to share the final findings of its Inquiry with the people of Afghanistan and other stakeholders through the media after receiving comments from MoFA, the High Council for Rule of Law and Anti-Corruption, and relevant donors and partners.

The Independent Joint Anti-Corruption Monitoring and Evaluation Committee (MEC) 